\title{
KARAKTERISTIK ANGKATAN KERJA DI PROVINSI SUMATERA SELATAN MENGGUNAKAN COMPOSITIONAL BIPLOT ANALYSIS
}

\author{
Oki Dwipurwani ${ }^{1}$, Dian Cahyawati ${ }^{2}$, Eka Susanti ${ }^{3}$ \\ Universitas Sriwijaya ${ }^{1,2,3}$ \\ e-mail: 'okidwip@unsri.ac.id
}

\begin{abstract}
Abstrak
Penelitian ini bertujuan untuk mendeskripsikan data komposisi angkatan kerja setiap kabupaten di Provinsi Sumatera Selatan (Sumsel). Salah satu metode deskripsi yang memberikan pemetaan berupa tampilan grafik dua dimensi pada data komposisi adalah Compositional Biplot Analysis (CBA). Hasil yang diperoleh adalah empat buah tampilan grafik CBA dengan informasi yang dapat diterangkan oleh setiap grafik lebih dari 85\%. Kota Palembang, Kabupaten Banyuasin, Musi Rawas Utara, PALI, Musi Banyuasin, Muara Enim, Lubuk lingau, OKU, dan Prabumulih berada dalam satu klaster yang memiliki penduduk angkatan kerja sebagai pengangguran terbuka diatas rata-rata klaster lainnya, dan memiliki nilai TKT di atas 3,50.
\end{abstract}

Kata kunci: Compositional Biplot Analysis (CBA), Data ketenagakerjaan

\begin{abstract}
This study aims to describe the compositional data of the workforce in each district of South Sumatra Province (Sumsel). One method of description that provides mapping in the form of a two-dimensional graphic display on composition data is Compositional Biplot Analysis (CBA). The results obtained are four CBA graphic displays with information that can be explained by more than $85 \%$ of each graph. Palembang City, Banyuasin Regency, Musi Rawas Utara, PALI, Musi Banyuasin, Muara Enim, Lubuk Lingau, OKU, and Prabumulih are in one cluster which has an open unemployed workforce population above the average of the other clusters and has a TKT value above. 3.50.
\end{abstract}

Keywords: Compositional Biplot Analysis (CBA), Employment data 


\section{PENDAHULUAN}

Salah satu masalah ketenagakerjaan di Provinsi Sumatera Selatan (Sumsel) adalah Tingkat Pengangguran Terbuka (TPT) yang terus meningkat dari tahun ke tahun, dimana pada tahun 2018 TPT sebesar 4,27 persen, TPT tahun 2019 sebesar 4,53 persen dan TPT tahun 2020 sebesar 5,51 persen. Kota Palembang memiliki TPT tertinggi yaitu sebesar 7,94 persen pada tahun 2019 dibandingkan kabupaten lainnya (BPS, 2020). Selain itu belum adanya pemerataan lapangan pekerjaan di setiap kabupaten/kota, hal ini dapat dilihat dari jumlah industri besar maupun sedang yang kebanyakan dibangun di kota Palembang sebanyak 80 industri dan Kabupaten Banyuasin hingga 70 industri, namun kabupaten lainnya ada yang hanya sedikit dan tidak ada sama sekali industri. (BPS, 2019a). Tenaga kerja yang ada pun masih belum optimal produktifitasnya, karena rata-rata tenaga kerja yang bekerja belum memberikan output seperti yang diharapkan, dengan rata-rata upah bersih 1.873.688 rupiah, berada dibawah rata-rata upah seluruh provinsi sebesar 2.432.097 rupiah (BPS, 2019b). Penyerapan penduduk angkatan kerja untuk bekerja oleh lapangan pekerjaan yang ada sekarang juga masih kurang, karena masih terdapat pengagguran terbuka. Sehingga masyarakat diharapkan dapat membangun usaha sendiri. Balai latihan kerja pada Dinas tenaga kerja atau pun pada Dinas Koperasi dan Usaha Mikro, Kecil dan Menengah (UMKM) perlu dimaksimalkan, sehingga diharapkan dapat meningkatkan keterampilan angkatan kerja untuk dapat berwirausaha. (Irwanto, 2019). Masalah ini juga diharapkan dapat diatasi dengan menciptakan lapangan pekerjaan oleh masing-masing pemerintah daerah ataupun pusat, dan tentunya setiap daerah memiliki karakteristik angkatan kerja yang berbeda-beda. Sehingga memerlukan gambaran karakteristik angkatan kerja di setiap kabupaten/kota. Pada penelitian ini dibatasi pada karakteristik angkatan kerja berdasarkan jenis kegiatan dan pendidikan, serta karakteristik angkatan kerja yang bekerja berdasarkan lapangan pekerjaan utama dan status pekerjaan utama. Dengan adanya gambaran karakteristik angkatan kerja, diharapkan pemerintah pusat dapat mengatasi pengangguran sesuai karakteristik kabupaten/Kota.

Menggambarkan karakteristik angkatan kerja setiap kabupaten di Provinsi Sumsel dapat dilakukan melalui pendeskripsian data dalam bentuk tampilan grafik atau plot dua dimensi, salah satunya adalah metode Biplot. Metode biplot yang digunakan disini adalah Compositional Biplot Analysis (CBA), karena data yang terlibat dalam penelitian ini berbentuk komposisi (compositional data). Compositional data adalah data yang memiliki komposisi lengkap biasanya berjumlah 100 jika dinyatakan dalam persen, atau bernilai 1 jika dinyatakan dalam proporsi. Jika digunakan pendekatan analisis statistika standar atau klasik pada compositional data, maka akan banyak peringatan kesalahan, sehingga disarankan menggunakan pendekatan log-Rasio (lr). (Lloyd et al., 2012).

Adapun penggunaan compositional data pada penelitian ini karena dalam membandingkan daerah yang satu dengan daerah yang lain berdasarkan variabelvariabelnya akan lebih baik jika menggunakan data berbentuk komposisi. Misalnya membandingkan penduduk angkatan kerja yang bekerja di Kota Palembang dengan penduduk angkatan kerja yang bekerja di Kabupaten Pagar Alam. Jumlah angkatan kerja yang bekerja di Kota Palembang sebanyak 698.873 jiwa, sementara itu di Kabupaten Pagar Alam sebanyak 69.309 jiwa, maka berdasarkan data tersebut tampak seolah-olah Kota Palembang lebih baik dalam menyediakan lapangan pekerjaan, karena jumlah angkatan kerjanya yang terserap di sejumlah lapangan pekerjaan lebih banyak dibandingkan dengan Kabupaten Pagar Alam. Cara membandingkan seperti ini akan memberikan kesimpulan yang tidak tepat. Perlu diperhatikan bahwa jumlah penduduk angkatan kerja di Kota Palembang jauh lebih besar yaitu 759.115 jiwa, dengan komposisi penduduk angkatan kerja yang bekerja sebesar 92,06\% dan 
yang merupakan pengangguran terbuka 7,94\%. Dibandingkan dengan jumlah penduduk angkatan kerja di Kabupaten Pagar Alam yaitu 71.050 jiwa, hampir sepersepuluh dari jumlah penduduk di Kota Palembang, dengan komposisi penduduk angkatan kerja yang bekerja sebesar 97,55\% dan yang merupakan pengangguran terbuka $2,45 \%$. Sehingga sebaiknya yang dibandingkan adalah data komposisi angkatan kerja yang berbentuk persentase ataupun rasio, bukan data jumlah penduduk angkatan kerjanya. Data-data yang disediakan oleh Badan Pusat Statistik (BPS) pun banyak berbentuk data komposisi.

Penelitian sebelumnya tentang ketenagakerjaan pernah dilakukan oleh Anik dkk (1016), yang melakukan penelitian tentang deskripsi data ketenagakerjaan menggunakan metode SQRT biplot (Square Root Biplot) terhadap data jumlah penduduk usia kerja yang bekerja di setiap kabupaten di Jawa Tengah. Grafik biplot yang dihasilkan memiliki kesesuaian grafik sebesar 64,19\%. (Anik Nurul Aini, Diah Safitri, 2016). Penelitian lainnya dilakukan oleh Arief dkk (2018) tentang analisis angka tenaga kerja di Kota Malang menggunakan Analisis Biplot dan Korespondensi. Data yang digunakan berbentuk rating dengan menghasilkan empat buah grafik biplot dengan kesesuaian grafik biplot masing-masing 63,5\%, 77,3\%, $63,5 \%$ dan $60,0 \%$. (Zubaidy \& Handoyo, 2018) Penelitian-penelitian tersebut menggunakan metode biplot klasik dan hanya memiliki kesesuaian grafik yang umumnya masih belum diatas $70 \%$.

Berdasarkan uraian diatas maka tujuan penelitian ini adalah untuk melakukan deskripsi pada data penduduk angkatan kerja di Provinsi Sumsel, berupa tampilan biplot dua dimensi,menggunakan metode $C B A$. Data yang digunakan berskala pengukuran rasio yaitu pesentase, dan nilainilai variabelnya membentuk komposisi.

\section{METODE}

\section{Data Komposisi (Compositionan Data)}

Pada data survei yang besar, yang melibatkan jumlah anggota populasi yang besar sampai ribuan, dengan ciri-ciri populasi yang heterogen, di berbagai bidang penelitian, sering ditemukan bentuk data komposisi (compositional data). Data tersebut dicirikan oleh informasi yang bukan berupa data absolut dari variabelvariabelnya, tetapi dari nilai rasio yang mengandung informasi yang penting. Compositional data diwakili oleh nilai proporsi atau persentase, dengan batasan jumlah yang konstan. (Pawlowsky-Glahn, V., Buccianti, 2011).

Sifat dari pemusatan pada biplot berlaku hanya untuk variabel dengan skala pengukuran interval, karena hasil invarian berhubungan dengan perubahan aditif dalam variabel. Jika data memiliki skala pengukuran rasio, dan jika perbedaan dalam perbandingan individu (objek) ingin digambarkan, dengan data berbentuk compositional, maka data harus ditransformasikan secara logaritma terlebih dahulu sebelum dilakukan pemusatan pada biplot.

Misalkan terdapat matriks compositional data $\mathbf{X}$ yang memiliki kolom-kolom yang bersesuaian dengan komponen dari compositional sebanyak $p$ bagian, dengan objek sebanyak $n$, maka vektor bagian dari matriks $\mathbf{X}$ adalah $\left[\boldsymbol{x}_{1}, \boldsymbol{x}_{2}, \ldots, \boldsymbol{x}_{p}\right]$. Dimana unsur-unsur $\boldsymbol{x}_{\boldsymbol{j}}$ bernilai positif dan memiliki sifat bahwa $x_{i 1}+x_{i 2}+\cdots+x_{i p}=1, \quad$ dengan $i=$ $1,2, \ldots, n$ dan $j=1,2, \ldots, p$. (Aitchison \& Greenacre, 2002)

\section{Transformasi Logratio (lr) dengan algoritma centred log-ratios $(\mathrm{Clr})$}

Kita misalkan bahwa logaritma unsur-unsur matriks data compositional $\mathbf{X}$ adalah $l_{i j}=\log \left(x_{i j}\right)$ dan terkoleksi dalam suatu matriks $\mathbf{L}(n \times p)$. Kemudian ditentukan bahwa dot subscript yaitu $l_{i}, l_{. j}$ dan $l .$. didenotasikan sebagai rata-rata unsur-unsur matriks $\mathbf{L}$ yang bersesuaian, maka centred log-ratios (Clr) setiap unsur matriks $\mathbf{X}$ adalah $\operatorname{Clr}\left(x_{i j}\right)=l_{i j}-l_{i}$. Selanjutnya, misalkan matriks $\mathbf{Z}$ adalah matriks berukuran $n \times p$ yang merupakan matriks row-centred log-ratios (Clr) dan terpusat terhadap rata-rata kolom, maka 
$z_{. j}=l_{. j}-l_{. .,} \quad$ dan $\quad z_{i j}=C \operatorname{lr}\left(x_{i j}\right)-l_{. j}+$ $l_{. .}=l_{i j}-l_{i .}-l_{. j}+l_{. .} \quad$ Sehingga $\quad z_{i j}$ merupakan unsur-unsur dari matriks $\mathbf{Z}$ yang berasal dari unsur-unsur matriks $\mathbf{L}$ yang terpusat berganda (double centred). (Aitchison \& Greenacre, 2002)

\section{Compositional Biplot Analysis (CBA)}

Biplot Analysis adalah teknik statistik deskriptif dimensi ganda yang disajikan secara visual dan simultan segugus objek pengamatan dan variabel dalam suatu grafik pada suatu bidang datar dua dimensi. Sehingga dapat dilihat sifat antara objekobjek pengamatan, antara setiap variabel, dan antara objek dengan variabel. (Jolliffe, I, 2002)

Tampilan grafik $C B A$ berdimensi rendah, khususnya dua dimensi, dapat diperoleh dengan menggunakan Singular Value Decomposition (SVD) terhadap matriks $\mathbf{Z}$, yaitu:

$$
\mathbf{Z}=\mathbf{U} \Gamma \mathbf{V}^{\mathbf{T}}
$$

dengan matriks $\mathbf{U}$ dan matriks $\mathbf{V}$ semuanya terpusat, dan rank matriks $\mathbf{Z}$ adalah $p-1$. Matriks $\mathbf{U}$ dan matriks $\mathbf{V}$ masing-masing merupakan matriks vektor singular kiri dan kanan, masing-masing

Tabel 1. Data dan variabel yang digunakan dengan $r$ ortonormal kolom, dan $\boldsymbol{\Gamma}$ adalah matriks diagonal dari $r$ nilai singulir positif dalam urutan dari yang terbesar sampai yang terkecil (menurun), yaitu $\gamma_{1} \geq \cdots \geq$ $\gamma_{r}>0$.

Matriks $\mathbf{Z}$ dapat ditransformasi kedalam bentuk perkalian matriks $\mathbf{Z}=$ $\mathbf{F G}^{\mathbf{T}}$, sehingga dapat ditunjukkan bahwa $S V D$ matriks $\mathbf{Z}$ menjadi

$$
\mathbf{Z}=\mathbf{U} \boldsymbol{\Gamma} \mathbf{V}^{\mathbf{T}}=\mathbf{U} \boldsymbol{\Gamma}^{\alpha} \boldsymbol{\Gamma}^{1-\alpha} \mathbf{V}^{\mathbf{T}}=\mathbf{F G}^{\mathbf{T}}
$$

Dugaan matriks $\mathbf{Z}$ yaitu $\hat{\mathbf{Z}}$ memiliki dimensi lebih kecil, yaitu berdimensi $r^{*}$. Jika $r^{*}=2$ maka matriks $\mathbf{F}$ dan $\mathbf{G}$ adalah

$$
\begin{aligned}
& \mathbf{F}=\mathbf{U} \boldsymbol{\Gamma}^{\alpha}=\left(\begin{array}{ll}
\gamma_{1}^{\alpha} \mathbf{u}_{1} & \gamma_{2}^{\alpha} \mathbf{u}_{2}
\end{array}\right) \\
& \mathbf{G}=\boldsymbol{\Gamma}^{1-\alpha} \mathbf{V}^{\mathbf{T}}=\left(\begin{array}{lll}
\gamma_{1}^{1-\alpha} \mathbf{v}_{1} & \gamma_{2}^{1-\alpha} \mathbf{v}_{2}
\end{array}\right)
\end{aligned}
$$

untuk beberapa pilihan nilai $\alpha$. Umumnya memilih nilai $\alpha=1$ atau $\alpha=0$.

Kebaikan grafik biplot $C B A$ dapat diketahui melalui proporsi dari jumlah kuadrat nilai singulir yaitu $\left(\gamma_{1}^{2}+\cdots+\gamma_{r^{*}}^{2}\right) /\left(\gamma_{1}^{2}+\cdots+\gamma_{r}^{2}\right)$ hasilnya dalam bentuk persentase, dengan $r^{*}$ adalah

\begin{tabular}{|c|c|c|c|c|}
\hline No & $\begin{array}{l}\text { Kode } \\
\text { data }\end{array}$ & Nama data & Nama variabel & $\begin{array}{c}\text { Simbol } \\
\text { variabel }\end{array}$ \\
\hline \multirow[t]{3}{*}{1} & \multirow[t]{3}{*}{ Data-1 } & \multirow{3}{*}{$\begin{array}{l}\text { Data persentase penduduk } \\
\text { angkatan kerja berdasarkan jenis } \\
\text { kegiatan, } 2019\end{array}$} & Bekerja & $X_{11}$ \\
\hline & & & Pernah bekerja & $X_{12}$ \\
\hline & & & Tidak pernah bekerja & $X_{13}$ \\
\hline \multirow[t]{6}{*}{2} & \multirow[t]{6}{*}{ Data-2 } & \multirow{6}{*}{$\begin{array}{lcr}\text { Data } \quad \text { persentase } & \text { penduduk } \\
\text { angkatan } & \text { kerja } & \text { berdasarkan } \\
\text { pendidikannya 2019 } & \end{array}$} & Belum pernah sekolah & $X_{21}$ \\
\hline & & & Tidak tamat SD & $X_{22}$ \\
\hline & & & SD & $X_{23}$ \\
\hline & & & SMP & $X_{24}$ \\
\hline & & & SMA & $X_{25}$ \\
\hline & & & Universitas & $X_{26}$ \\
\hline \multirow[t]{3}{*}{3} & \multirow[t]{3}{*}{ Data-3 } & \multirow{3}{*}{$\begin{array}{l}\text { Data persentase penduduk angkatar } \\
\text { kerja yang bekerja berdasarkar } \\
\text { lapangan pekerjaan utama } 2019\end{array}$} & Pertanian & $X_{31}$ \\
\hline & & & Industri pengolahan & $X_{32}$ \\
\hline & & & Jasa & $X_{33}$ \\
\hline \multirow[t]{7}{*}{4} & \multirow[t]{7}{*}{ Data-4 } & \multirow{7}{*}{$\begin{array}{l}\text { Data persentase penduduk } \\
\text { angkatan kerja yang bekerja } \\
\text { berdasarkan status pekerjaan utama } \\
2019\end{array}$} & Berusaha sendiri & $X_{41}$ \\
\hline & & & Berusaha dibantu buruh tidak tetap & $X_{42}$ \\
\hline & & & Berusaha dibantu buruh tetap & $X_{43}$ \\
\hline & & & Buruh/Karyawan/Pegawai & $X_{44}$ \\
\hline & & & Pekerja bebas pertanian & $X_{45}$ \\
\hline & & & Pekerja bebas non pertanian & $X_{46}$ \\
\hline & & & Pekerja tidak dibayar & $X_{47}$ \\
\hline
\end{tabular}
dimensi grafik. (Aitchison \& Greenacre, 2002)

\section{Data dan Variabel yang Digunakan}

4 | Jurnal Aplikasi Statistika \& Komputasi Statistik V.12.2.2020, ISSN 2086-4132 
Data yang digunakan dalam penelitian ini terdiri dari empat buah data, yang masing-masing data memiliki tujuh belas objek mewakili kabupaten/Kota dan beberapa variabel. Setiap data akan di deskripsikan dalam bentuk tampilan biplot $C B A$, sehingga ada empat buah tampilan biplot $C B A$. Empat buah data tersebut tentang penduduk angkatan kerja di Sumsel, dengan skala pengukuran rasio yaitu persentase. Data pertama adalah data tentang penduduk angkatan kerja menurut jenis kegiatan (Data - 1) yang memiliki tiga variabel. Data ke dua adalah data tentang penduduk angkatan kerja menurut pendidikan terakhir (Data - 2) yang memiliki enam variabel. Data ke tiga adalah data tentang penduduk angkatan kerja yang bekerja menurut lapangan pekerjaan Utama (Data - 3) yang memiliki tiga variabel. Data ke empat adalah penduduk angkatan kerja yang bekerja menurut status pekerjaan utama (Data - 4) yang memiliki tujuh variabel. Lebih lengkapnya mengenai kode data, nama data, nama variabel dan simbol variabel dapat dilihat pada Tabel 1 .

Selanjutnya, data-data penelitian tentang angkatan kerja di Provinsi Sumsel, berupa data sekunder didapat dari Badan
Pusat Statistik (BPS) Sumsel. Data-1 sampai Data-4 diperoleh dari katalog Keadaan Angkatan Kerja di Provinsi Sumsel untuk tahun 2019. (BPS, 2019c)

Langkah-langkag penelitian dan pengolahan data menggunakan $C B A$ dapat melalui langkah-langkah pada bagan Gambar 1. Untuk mempermudah pengolahan data, dibantu software $R$, melalui paket Rob Compositional (Templ M, Hron K, 2011)

\section{HASIL DAN PEMBAHASAN}

Data sekunder yang diperoleh dari Badan Pusat Statistik (BPS) Sumsel, berupa hasil Survei Angkatan Kerja Nasional (SAKERNAS) yang dilaksanakan di Provisnsi Sumatera Selatan pada bulan Agustus 2019 yang telah dipublikasikan (BPS, 2019c). Data yang diolah berupa persentase jumlah penduduk angkatan kerja di setiap kabupaten di Sumsel yang berjumlah 17 kabupaten/kota, berdasarkan jenis kegiatan, pendidikan tertinggi, lapangan pekerjaan utama, dan status pekerjaan utama tahun 2019.

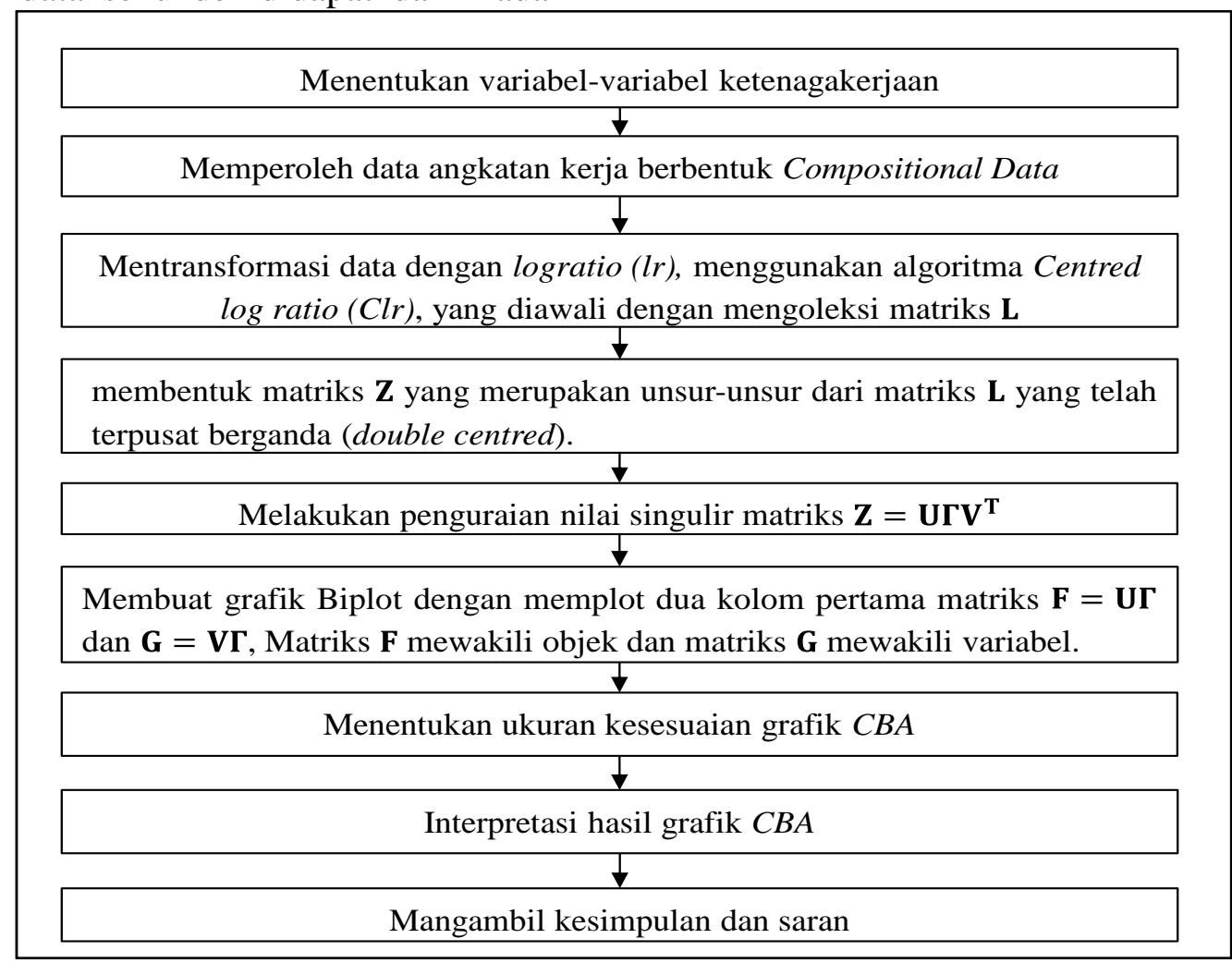

Gambar 1. Langkah-langkah penelitian dan pengolahan data dengan $C B A$ 


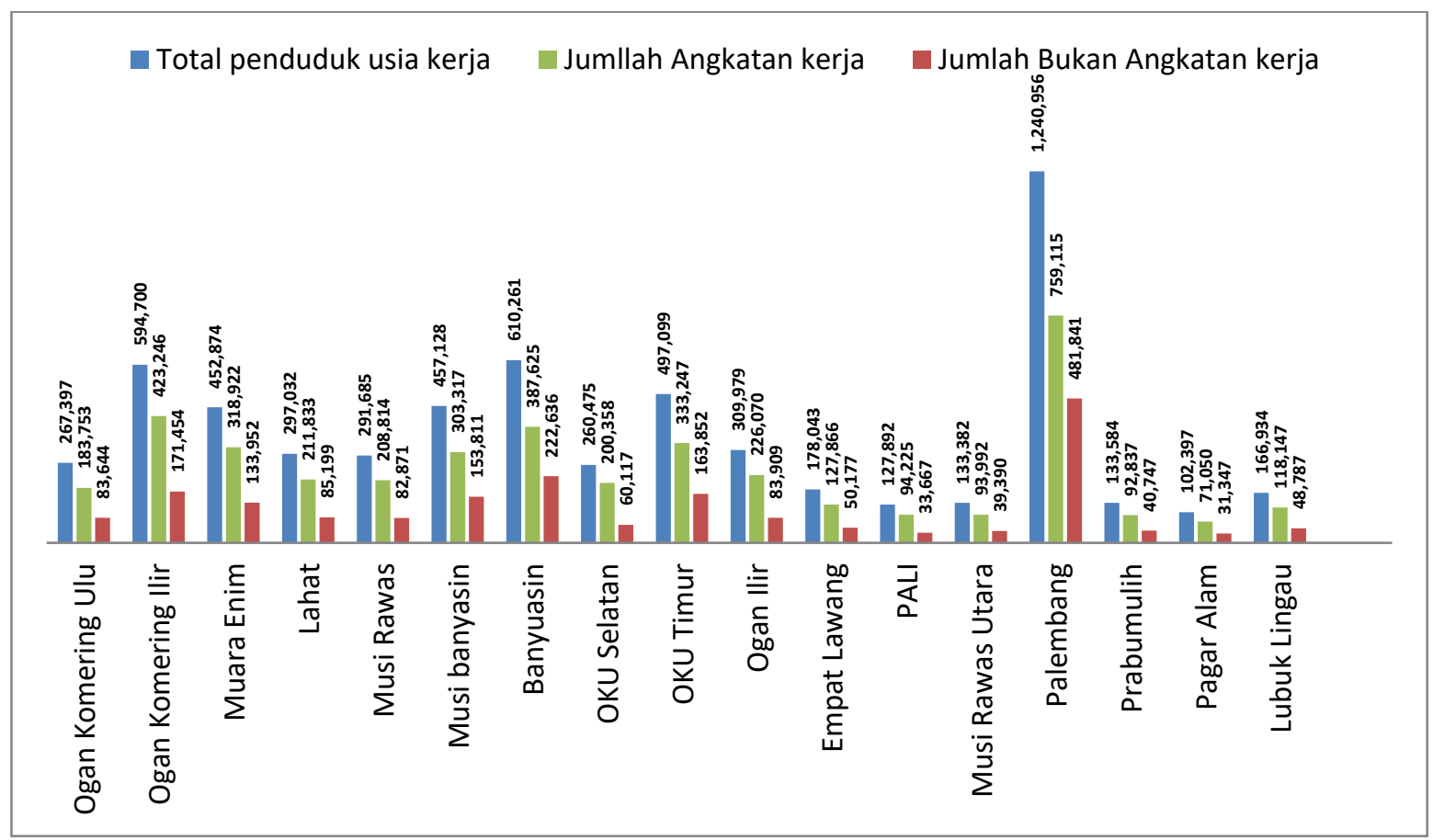

Gambar 2. Jumlah Penduduk angkatan kerja di Kabupaten/Kota di Sumsel

Jumlah penduduk usia kerja, yaitu penduduk dengan usia diatas 15 tahun, penduduk angkatan kerja dan bukan angkatan kerja untuk setiap kabupaten di Provinsi Sumsel dapat dilihat pada Gambar 2. Pada Gambar 2 tersebut tampak bahwa Kota Palembang memiliki jumlah penduduk usia kerja hampir dua kali lipat dari kabupaten lainnya. Kota Palembang juga memiliki jumlah penduduk angkatan kerja dan bukan angkatan kerja terbesar.
Kabupaten Pagar alam memiliki jumlah penduduk usia kerja terkecil.

Tingkat Partisipasi Angkatan Kerja (TPAK) dan Tingkat Pengangguran Terbuka (TPT) di setiap kabupaten dapat dilihat dari tampilan Gambar 3. Tampak dalam Gambar 3, Kota Palembang memiliki tingkat TPAK paling rendah yaitu 61,17 persen, artinya terdapat 61,17 penduduk angkatan kerja setiap 100 penduduk usia kerja. Tetapi Kota Palembang memiliki

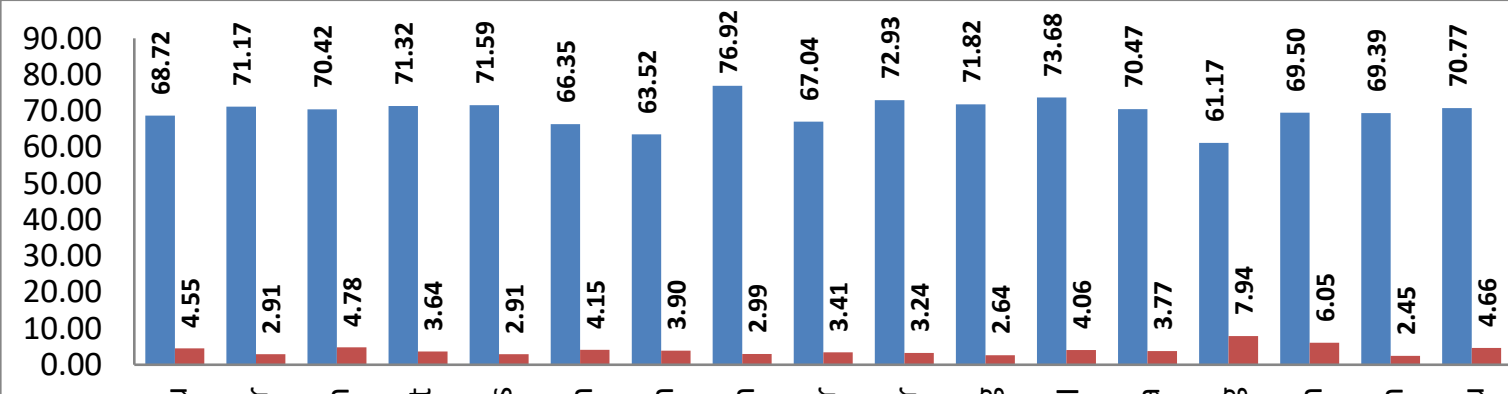

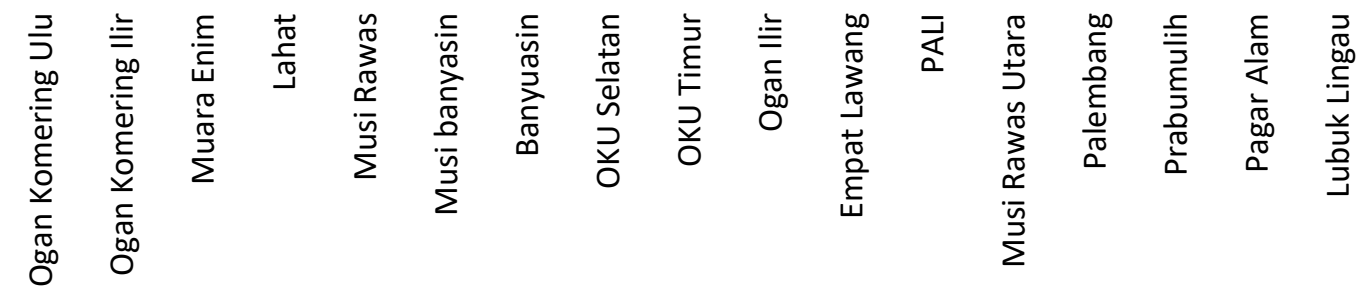

$$
\begin{aligned}
& \text { —TPAK (\%) — TPT (\%) }
\end{aligned}
$$

Gambar 3. Nilai TPAK dan Nilai TPT 
tingkat pengangguran terbuka paling tinggi yaitu 7,94 persen, artinya terdapat 7,94 penduduk angkatan kerja yang menjadi pengangguran terbuka setiap 100 penduduk angkatan kerja di Kota Palembang. Kabupaten OKU Selatan memiliki TPAK tertinggi yaitu sebesar 76,92 persen. Kabupaten Pagaralam memiliki TPT paling rendah, yaitu 2,45 persen.

\section{Compositional Biplot Analysis (CBA)}

Dari empat buah data yang akan diolah menggunakan $C B A$, data pertama adalah data persentase penduduk angkatan kerja berdasarkan jenis kegiatan (Data-1). Matriks data $\mathbf{X}$ pada Data-1 memiliki 17 baris yang mewakili jumlah kabupaten/kota dan memiliki 3 kolom yang mewakili jumlah variabel, yaitu variabel bekerja $\left(X_{11}\right)$, variabel pernah bekerja $\left(X_{12}\right)$ dan variabel tidak pernah bekerja $\left(X_{13}\right)$. Sehingga pada baris pertama dan kolom pertama matriks $\mathbf{X}$ menunjukan persentase penduduk angkatan kerja yang memiliki jenis kegiatan bekerja di kabupaten Ogan Komering Ulu. Data dalam bentuk komposisi, sehingga jumlah setiap baris pada matriks data $\mathbf{X}$ bernilai 100 persen atau satu.

Kemudian metode Log-ratio (lr) yaitu algoritma Centred log ratio (Clr) diaplikasikan pada data $\mathbf{X}$. Pertama-tama diperoleh matriks $\mathbf{L}$, dengan unsur baris pertama dan kolom pertama matriks $\mathbf{L}$ bernilai $\quad l_{11}=\log \left(x_{11}\right)=\log (95,45)=$ 1,979 , demikian seterusnya untuk nilainilai $l_{i j}$ lainnya pada matriks $\mathbf{L}$. Selanjutnya, diperoleh nilai $\operatorname{Clr}\left(x_{11}\right)=$ $l_{11}-l_{1}=1,979-[(1,979+0,446+$ $0,244) / 3]=1,979-0,890=1,089$, yaitu pemusatan terhadap baris pada matriks $\mathbf{L}$, demikian seterusnya dengan cara serupa untuk nilai-nilai $\operatorname{Cl}\left(x_{i j}\right)$ lainnya. Sehingga untuk memperoleh matriks $\mathbf{Z}$ dilakukan pemusatan terhadap kolom dan baris pada matriks L. Nilai $z_{11}=$ $\operatorname{Clr}\left(x_{11}\right)-l_{.1}+l_{. .}=1,089-$ $\left[\frac{(1,979+\cdots+1,979)}{17}\right]+0,818=-0,075$,

demikian seterusnya untuk nilai-nilai $z_{i j}$ lainnya, sehingga diperoleh matriks $\mathbf{Z}$ yang juga berukuran 17 baris dan 3 kolom.
Matriks X, L, dan $\mathbf{Z}$ beserta unsurunsurnya adalah sebagai berikut:

$$
\begin{gathered}
\mathbf{X}=\left[\begin{array}{ccc}
95,45 & 2,80 & 1,75 \\
97,09 & 0,93 & 1,98 \\
95,22 & 1,54 & 3,24 \\
96,36 & 1,46 & 2,17 \\
97,09 & 0,87 & 2,04 \\
95,85 & 0,86 & 3,29 \\
96,10 & 1,23 & 2,67 \\
97,01 & 0,30 & 2,69 \\
96,59 & 1,00 & 2,41 \\
96,76 & 0,89 & 2,35 \\
97,36 & 1,04 & 1,60 \\
95,94 & 0,89 & 3,16 \\
96,23 & 0,83 & 2,94 \\
92,06 & 3,91 & 4,03 \\
93,95 & 4,32 & 1,73 \\
97,55 & 1,07 & 1,38 \\
95.34 & 2,64 & 2,02
\end{array}\right] \\
\mathbf{L}
\end{gathered}
$$




$$
\mathbf{Z}=\left[\begin{array}{ccc}
-0,075 & 0,272 & -0,198 \\
0,073 & -0,067 & -0,005 \\
-0,078 & 0,012 & 0,066 \\
-0,009 & 0,053 & -0,044 \\
-0,078 & 0,235 & -0,148 \\
0,006 & -0,160 & 0,154 \\
-0,015 & -0,027 & 0,042 \\
0,190 & -0,436 & 0,245 \\
0,031 & -0,071 & 0,040 \\
0,053 & -0,103 & 0,050 \\
0,087 & -0,003 & -0,084 \\
0,007 & -0,144 & 0,137 \\
0,029 & -0,155 & 0,126 \\
-0,254 & 0,254 & -0,001 \\
-0,140 & 0,403 & -0,263 \\
0,105 & 0,027 & -0,132 \\
-0,087 & 0,235 & -0,148
\end{array}\right]
$$

Matriks $\mathbf{F}$ dan $\mathbf{G}$ diperoleh dari hasil $S V D$ dari matriks Z. Grafik $C B$ diperoleh dengan memplot dua kolom pertama matriks $\mathbf{F}$ mewakili kabupaten dan dua kolom pertama matriks $\mathbf{G}$ mewakili variabel ketenagakerjaan. Hasil Plot matriks F dan G dapat dilihat pada Gambar 4.

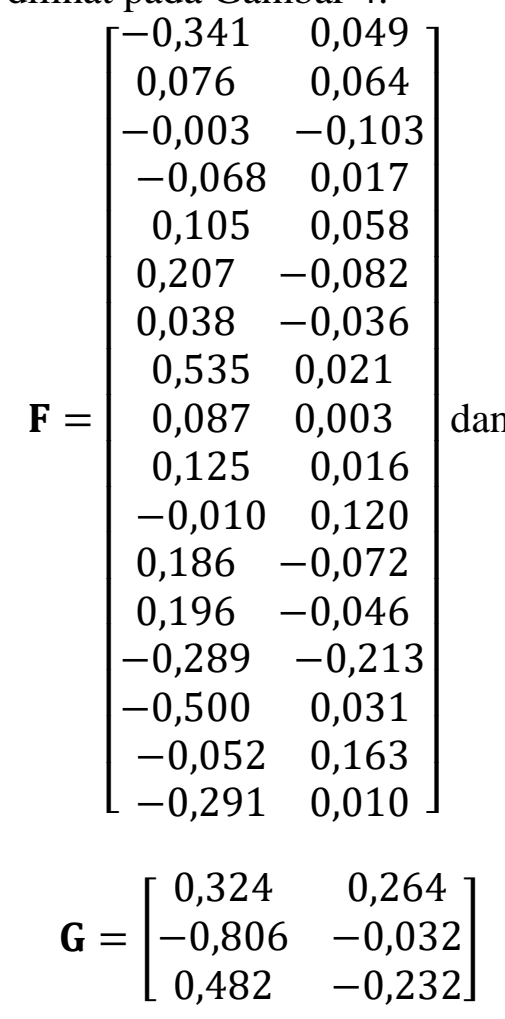

Nilai singulir yang diperoleh dari hasil $S V D$ matriks $\mathbf{Z}$ adalah $\gamma_{1}=0,993$, $\gamma_{2}=0,353$ dan $\gamma_{3}=0,000$, sehingga kesesuaian atau kebaikan grafik $C B$ yang terbentuk adalah sebesar $\left(\gamma_{1}^{2}+\gamma_{2}^{2}\right) /\left(\gamma_{1}^{2}+\gamma_{2}^{2}+\gamma_{3}^{2}\right)=$ $\frac{(0,987+0,124)}{(0,987+0,124+0)}=1$. Nilai ini memberi arti bahwa besarnya keragaman data asal yang diterangkan oleh grafik biplot tersebut yaitu sebesar $100 \%$, bisa dikatakan bahwa grafik $C B$ sudah baik. Untuk selanjutnya grafik $C B$ untuk Data-1 ditulis grafik $C B \_1$.

Dalam mengiterpretasikan gambar Biplot $C B$, dapat dilakukan dengan memperhatikan aspek-aspek berikut: Pertama, dengan melihat kedekatan antar kabupaten. Kabupaten yang berdekatan memiliki karakteristik yang sama dan dapat membentuk satu klaster. Kedua, dengan melihat panjang pendeknya vektor variabel. Variabel dengan keragaman yang kecil akan ditunjukan oleh vektor variabel yang pendek, demikian sebaliknya. Ketiga, korelasi antara variabel ditunjukan oleh sudut yang dibentuk vektor variabel. Semakin kecil sudut yang dibentuk kurang dari $90^{\circ}$ maka korelasinya bernilai positif, jika sudut yang dibentuk lebih besar dari $90^{\circ}$ maka korelasinya negatif, namun jika sudut yang dibentuk hampir membentuk sudut $90^{\circ}$ maka korelasinya mendekati nol. Keempat, karakteristik suatu kabupaten ditunjukan oleh posisi relatifnya terhadap vektor variabel.

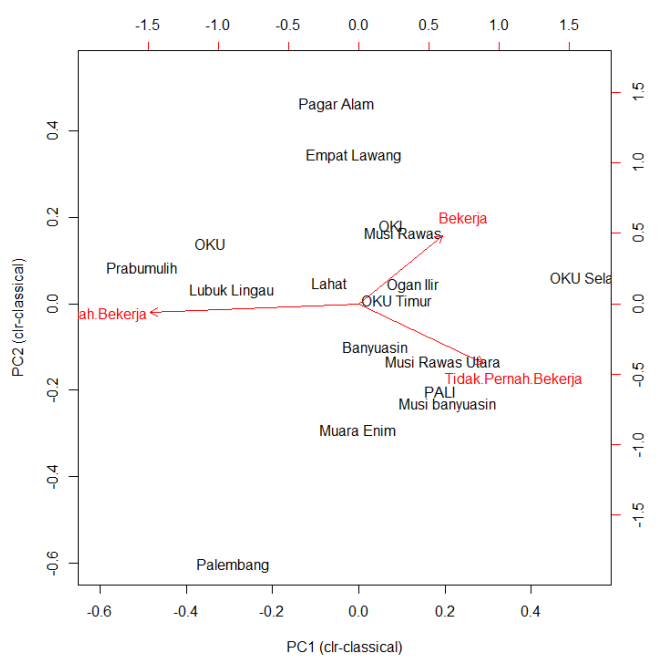

Gambar 4. Grafik $C B \_1$ kabupaten dan jenis kegiatan penduduk angkatan kerja

Berdasarkan Gambar 4, terlihat pengelompokan kabupaten dengan karakteristik yang sama. Penomoran klaster dimulai dari bawah ke atas, dan dari kiri ke kanan. Klaster 1 adalah Palembang, dan 
klaster 2 adalah Banyuasin, Musi Rawas Utara, PALI, Musi Banyuasin, Muara Enim. Klaster 3 adalah Prabumulih, Lubuk Lingau, serta OKU. Klaster 4 adalah OKI, Musi Rawas, Lahat, Ogan Ilir, OKU Timur. Klaster 5 adalah OKU selatan. Klaster 6 adalah Pagar Alam dan Empat Lawang. Keragaman terbesar adalah variabel pernah bekerja. Korelasi antara variabel bekerja dan tidak pernah bekerja kecil, karena sudut yang dibentuk antara kedua vektor variabel membentuk sudut mendekati 90 derajat.

Klaster 1 memiliki karakteristik persentase penduduk angkatan kerja yang pernah bekerja dan tidak pernah bekerja yang tinggi dibandingkan klaster lainnya. Hal ini ditunjukan oleh grafik $C B \_1$ dimana Kota Palembang ada di antara kedua vektor variabel tersebut dan letaknya sangat jauh dari titik pusat. Persentase penduduk angkatan kerja yang bekerja pada klaster 1 cukup rendah, berada dibawah rata-rata persentase klaster lainnya, terlihat dari letak Kota Palembang pada grafik $C B \_1$ berada pada arah yang berlawanan dengan vektor variabel bekerja.

Klaster 2 memiliki karakteristik persentase penduduk angkatan kerja yang tidak pernah bekerja diatas rata-rata persentase klaster lainnya. Klaster 3 memiliki karakteristik persentase penduduk angkatan kerja yang pernah bekerja lebih tinggi dibanding klaster lainnya, karena tampak pada grafik $C B_{-} 1$ kabupatenkabupaten pada klaster 3 letaknya searah dan berdekatan dengan vektor variabel pernah bekerja. Klaster 2 dan klaster 3 juga memiliki karakteristik pengangguran terbuka diatas rata-rata klaster lainnya.

Klaster 4 adalah kabupatenkabupaten dengan karakteristik persentase penduduk angkatan kerja yang bekerja diatas rata-rata kabupaten-kabupaten pada klaster 1, 2, dan 3. Klaster 5 memiliki karakteristik persentase penduduk angkatan kerja yang bekerja dan tidak pernah bekerja cukup tinggi, dan persentase penduduk yang pernah bekerja rendah. Klaster 6 memiliki karakteristik persentase penduduk angkatan kerja yang sudah bekerja lebih tinggi dibandingkan kabupaten pada klaster lainnya.
Berdasarkan hasil interpretasi grafik CB_1 pada Gambar 4, klaster 1, klaster 2 dan klaster 3 adalah kabupaten-kabupaten dengan penduduk angkatan kerja banyak yang menjadi pengangguran terbuka. Khususnya klaster 2 memiliki penduduk angkatan kerja yang belum pernah bekerja lebih tinggi dari klaster lainnya, hal ini perlu menjadi perhatian pemerintah daerah setempat. Misalnya perlu adanya pemberian keterampilan dan adanya balai-balai latihan kerja pada klaster 1, 2 dan 3. Klaster 1 yaitu Palembang memiliki jumlah penduduk angkatan kerja paling tinggi, persentase penduduk angkatan kerja yang menganggur juga tertinggi, sehingga perlu adanya perpindahan penduduk ke daerah lain. Klaster 4, 5 dan 6 pemerintah daerahnya dapat dikatakan telah cukup baik dalam mengatasi masalah pengangguran terbuka.

Grafik $C B \_2$ untuk perentase penduduk angkatan kerja berdasarkan pendidikan terakhir untuk setiap kabupaten dapat dilihat pada Gambar 5. Gambar 5 memiliki kesesuaian grafik $C B \_2$ sebesar 0,8694 , artinya bahwa besarnya keragaman data asal yang diterangkan oleh grafik $C B \_2$ sebesar $86,94 \%$. Apabila nilai kesesuaian mendekati satu ( $\geq 70 \%$ ), maka biplot yang dihasilkan memberikan penyajian yang semakin baik mengenai informasi data yang sebenarnya, (Mattjik \& Sumertajaya, 2011)(Gabriel, 1971)(Leleury \& Wokanubun, 2015).

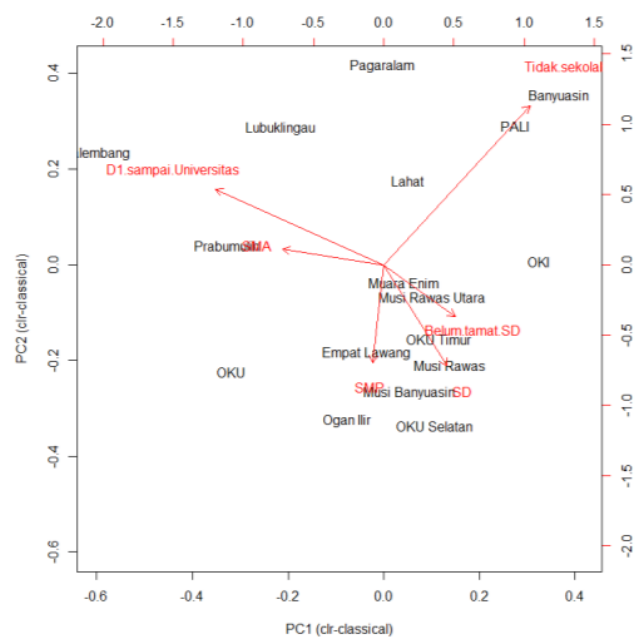

Gambar 5. Grafik $C B \_2$ kabupaten dan pendidikan terakhir penduduk angkatan kerja 
Pada Gambar 5, terdapat empat klaster. Variabel tidak sekolah atau persentase penduduk angkatan kerja yang belum pernah sekolah memiliki keragaman terbesar, dan variabel belum tamat SD memiliki keragaman terkecil. Beberapa variabel memiliki korelasi tinggi dan positif satu sama lain yaitu variabel belum tamat sekolah, variabel SD dan variabel SMP. Begitu juga terdapat korelasi tinggi dan positif antara variabel SMA dan variabel Universitas.

Klaster 1 yaitu Kabupaten OKU Memiliki karakteristik persentase penduduk angkatan kerja berpendidikan SMP dan SMA yang tinggi, dan hanya sedikit yang tidak sekolah dibandingkan klaster lainnya. Klaster 2 yang terdiri dari Kabupaten Muara Enim, Musi Rawas Utara, OKU Timur, Empat Lawang, Musi Rawas, Musi Banyuasin, Ogan Ilir dan OKU Selatan, memiliki karakteristik perentase penduduk angkatan kerja dengan pendidikan tertinggi adalah SD, SMP atau SMA. Klaster 3 yaitu Kabupaten Prabumulih, Lubuk lingau dan Kota Palembang memiliki karakteristik persentase angkatan kerja dengan pendidikan SMA dan Universitas yang tinggi. Klaster 4 Kabupaten OKI, Lahat, PALI, Banyuasin, dan Pagaralam memiliki karakteristik perentase angkatan kerja

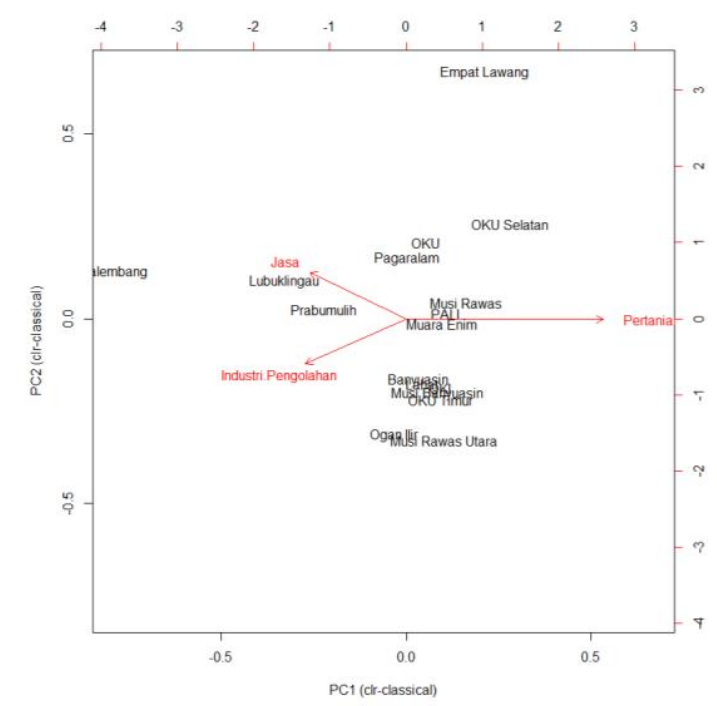

Gambar 6. $C B \_3$ Kabupaten dan lapangan pekerjaan utama angkatan kerja yang bekerja berpendidikan tidak sekolah yang tinggi dibandingkan klaster lainnya.

Hasil dari interpretasi grafik $C B \_2$ pada Gambar 5, dapat ditambahkan bahwa untuk klaster 2 dan klaster 4 perlu adanya usaha dalam meningkatkan pendidikan bagi penduduk angkatan kerjanya, khususnya yang masih berpendidikan SD sampai SMP, agar dapat lebih bersaing dengan Kabupaten-kabupaten lainnya dalam memperoleh pekerjaan.

Selanjutnya grafik $C B$ untuk perentase angkatan kerja yang bekerja berdasarkan lapangan pekerjaan utama untuk setiap kabupaten dapat dilihat pada Gambar 6. Gambar 6 memiliki kesesuaian grafik $C B \_3$ sebesar 1, artinya bahwa besarnya keragaman data asal yang diterangkan oleh grafik $C B \_3$ adalah sebanyak $100 \%$, dan bisa dikatakan grafik CB_3 sudah baik.

Pada gambar 6 tersebut tampak bahwa klaster 1 adalah Banyuasin, OKU Timur, Musi Banyuasin, Ogan Ilir, Musi Rawas Utara, Lahat. Klaster 2 adalah Musi Rawas, PALI, Muara Enim. Klaster 3 adalah Lubuk lingau, Prabumulih dan Palembang, membentuk klaster tersendiri. Klaster 4 adalah OKU dan Pagar Alam. Klaster 5 adalah OKU Selatan. Klaster 6 adalah Empat lawang. Variabel pertanian memiliki keragaman terbesar. Ada korelasi positif antara variabel Jasa dan Industri pengolahan. Hal ini menunjukan bahwa kabupaten/kota yang memiliki persentase penduduk angkatan kerja dengan lapangan pekerjaan utamanya di bidang Jasa yang tinggi maka persentase penduduk angkatan kerja yang bekerja di bidang industri pengolahannya juga tinggi, demikian sebaliknya.

Klaster 1 memiliki karakteristik persentase penduduk angkatan kerja yang bekerja di industri pengolahan dan pertanian tinggi. Klaster 2 memiliki karakteristik persentase penduduk angkatan kerja yang bekerja pada lapangan pekerjaan pertanian tinggi. Klaster 3 memiliki karakteristik persentase penduduk angkatan kerja yang bekerja dengan lapangan pekerjaan utama adalah Jasa dan industri pengolahan, hanya sedikit di pertanian. 
Klaster 4 memiliki karakteristik persentase penduduk angkatan kerja yang bekerja di bidang Jasa atau pertanian. Klaster 5 memiliki karakteristik persentase penduduk angkatan kerja yang bekerja di lapangan kerja pertanian. Klaster 6 memiliki karakteristik persentase penduduk angkatan kerja yang bekerja di lapangan pekerjaan pertanaian atau jasa, dengan sedikit yang bekerja di lapangan industri pengolahan.

Hasil dari interpretasi grafik $C B \_3$ pada Gambar 6, menunjukan bahwa klaster 5 dan klaster 6, yaitu Kabupaten OKU Selatan dan Empat lawang masih kurang adanya industri pengolahan. Jumlah industri yang ada di OKU Selatan hanya ada satu, yaitu Industri kemplang dengan produksi utamanya adalah kerupuk, dengan jumlah tenaga kerja tidak lebih dari 30 orang. Demikian juga di Kabupaten Empat lawang baru ada sebuah industri pengolahan dengan produksi utamanya adalah batu split, dengan tenaga kerja sekitar 40 orang. (BPS, 2019a)

Selanjutnya grafik $C B$ untuk perentase angkatan kerja yang bekerja berdasarkan status pekerjaan utama untuk setiap kabupaten dapat dilihat pada Gambar 7. Gambar 7 memiliki kesesuaian grafik CB_4 sebesar 0,8917 artinya bahwa besarnya informasi atau keragaman data asal yang diterangkan oleh grafik $C B \_4$ sebanyak $89,17 \%$, dan bisa dikatakan grafik CB_4 sudah baik.

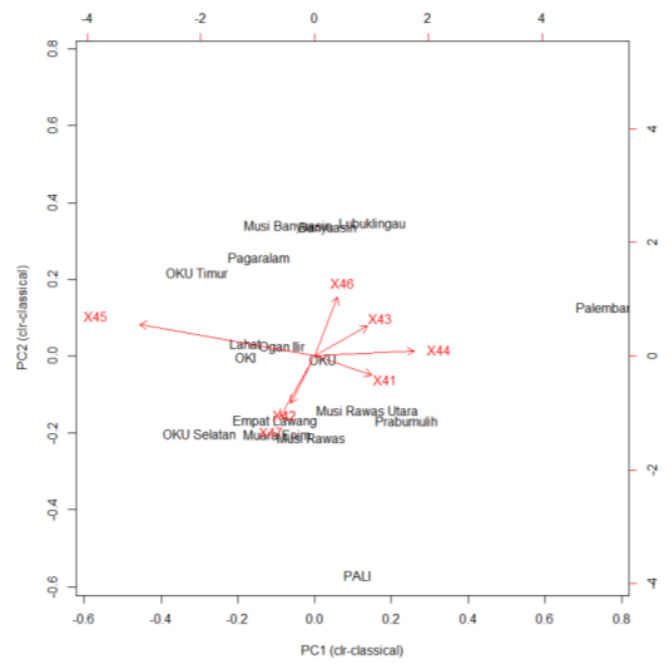

Gambar 7. $C B \_4$ Kabupaten dan status pekerjaan utama angkatan kerja yang bekerja
Untuk biplot $C B \_4$ pada Gambar 7, setiap Kabupaten/Kota cenderung menyebar berjauhan, sehingga timbul banyak pengklasteran kabupaten, khususnya Kota Palembang dan Kabupaten PALI membentuk klaster tersendiri yang letaknya jauh dari kabupaten lainnya. Jumlah variabel yang terlibat cukup banyak, ada 7 variabel. Variabel pekerja bebas pertanian $\left(X_{45}\right)$ memiliki keragaman terbesar. Variabel berusaha dibantu buruh tidak tetap $\left(X_{42}\right)$ dan Variabel pekerja tak dibayar $\left(X_{47}\right)$ memiliki korelasi yang sangat kuat karena kedua vektor variabelnya nyaris berhimpit.

Klaster 1 adalah Kabupaten PALI memiliki karakteristik persentase angkatan kerja yang bekerja dengan status pekerjaan utamanya berusaha sendiri dengan dibantu buruh tidak tetap $\left(X_{42}\right)$ dan pekerja yang tidak dibayar $\left(X_{47}\right)$.

Klaster 2 adalah OKU Selatan juga menjadi kabupaten yang membentuk kelompok sendiri dengan karakteristik persentase angkatan kerja yang bekerja dengan status pekerjaan utamanya kebanyakan mirip dengan PALI yaitu berusaha sendiri dengan dibantu buruh tidak tetap $\left(X_{42}\right)$ dan pekerja yang tidak dibayar $\left(X_{47}\right)$, namun OKU Selatan juga memiliki karakteristik persentase angkatan kerja yang sedikit bekerja menjadi buruh/pegawai $\left(X_{44}\right)$ dan berusaha sendiri dibantu buruh tetap $\left(X_{43}\right)$.

Klaster 3 yang terdiri dari Kabupaten Muara Enim, Musi Rawas dan Empat Lawang memiliki karakteristik persentase angkatan kerja yang bekerja dengan status pekerjaannya lebih banyak berusaha sendiri dengan dibantu buruh tidak tetap $\left(X_{42}\right)$ dan pekerja yang tidak dibayar $\left(X_{47}\right)$, serta sedikit yang memiliki status pekerjaan sebagai pekerja bebas non pertanian $\left(X_{46}\right)$ yaitu seseorang yang bekerja pada orang lain atau institusi dengan sifat tidak tetap tetapi memperoleh imbalan atau gaji.

Klaster 4 Musi Rawas Utara dan Prabumulih memiliki karakteristik persentase angkatan kerja yang bekerja kebanyakan dengan status berusaha sendiri $\left(X_{41}\right)$ yaitu adalah bekerja yang berani menanggung resiko secara ekonomi 
sendirian, dan tanpa memiliki pekerja lainnya. Angkatan kerja pada kabupatenkabupaten ini hanya sedikit yang statusnya sebagai pekerja bebas pertanian $\left(X_{45}\right)$.

Klaster 5 adalah Kabupaten OKU juga menjadi kelompok tersendiri, dimana persentase angkatan kerja yang bekerja tidak menunjukan karakteristik tertentu, karena letaknya hampir berada di pusat koordinat, menunjukan semua variabelnya memiliki nilai persentase rata-rata.

Klaster 6 adalah Kabupaten Lahat, Ogan Ilir dan OKI memiliki karakteristik persentase angkatan kerja yang bekerja dengan status pekerjaan sebagai pekerja bebas pertanian $\left(X_{45}\right)$ cukup banyak, dan letak klaster ini hampir berada di pusat koordinat.

Klaster 7 adalah Kota Palembang memiliki karakteristik perentase angkatan kerja yang bekerja dengan status pekerjaan utama terbanyak sebagai buruh/karyawan/pegawai $\left(X_{44}\right), \quad$ yaitu menjadi pekerja tetap pada suatu instansi atau perusahaan dengan gaji tetap. Status pekerjaan paling sedikit adalah pekerja bebas pertanian $\left(X_{45}\right)$, yaitu bekerja pada seseorang baik usaha rumah tangga maupun bukan usaha rumah tangga di bidang pertanian dengan mendapatkan bayaran yang sesuai.

Klaster 8 adalah OKU Timur dan Pagaralam memiliki karakteristik persentase angkatan kerja yang bekerja dengan status pekerjaan sebagai pekerja bebas pertanian $\left(X_{45}\right)$ dan pekerja bebas non pertanian $\left(X_{46}\right)$ diatas rata-rata kabupaten lainnya. Karena letak klaster 8 berada diantara kedua variabel tersebut dan jauh dari titik pusat.

Klaster 9 yaitu Kabupaten Musi Banyuasin, Banyuasin dan Lubuklingau memiliki karakteristik persentase angkatan kerja yang bekerja kebanyakan dengan status pekerjaan sebagai pekerja bebas non pertanian $\left(X_{46}\right)$. Sedikit yang bekerja dengan status pekerjaannya adalah berusaha sendiri dengan dibantu buruh tidak tetap $\left(X_{42}\right)$ dan pekerja yang tidak dibayar $\left(X_{47}\right)$.

Hasil dari interpretasi grafik $C B \_4$ pada Gambar 7 adalah perlu adanya perhatian untuk klaster dengan karakteristik persentase pekerja yang tidak dibayar $\left(X_{47}\right)$ cukup banyak, yaitu klaster 1, klaster 2 dan klaster 3. Persentase penduduk angkatan kerja yang bekerja dengan status sebagai buruh/karyawan/pegawai $\left(X_{44}\right)$ yang tinggi pada klaster 7, disebabkan oleh kebanyakan industri berada di kota Palembang, yaitu sekitar 80 industri baik industri besar maupun sedang.

\section{KESIMPULAN DAN SARAN}

Kesimpulan yang dapat diambil dari penelitian tentang ketenagakerjaan menggunakan grafik $C B$ adalah sebagai berikut:

1. Grafik-grafik biplot $C B$ yang dihasilkan telah baik, karena dapat memberikan informasi data asal lebih dari $70 \%$ untuk keempat gugus data.

2. Beberapa kabupaten/kota yang diklaster menjadi satu dan memiliki karakteristik persentase penduduk angkatan kerja sebagai pengangguran terbuka yang tinggi yaitu Palembang, Banyuasin, Musi Rawas Utara, PALI, Musi Banyuasin, Muara Enim, Lubuk lingau, OKU dan Prabumulih, perlu menjadi perhatian pemerintah daerah maupun pusat, agar dapat menurunkan tingkat pengangguran. Klaster ini juga memiliki TKT di atas 3,50.

3. Kota Palembang dengan jumlah penduduk terbesar di Sumsel memiliki TKT tertinggi, sehingga perlu adanya kebijakan dari pemerintah kota untuk melakukan pembatasan pertambahan jumlah penduduk, membatasi migrasi ke Kota Palembang dan mengupayakan migrasi dari kota Palembang ke kabupaten lainnya.

4. Kabupaten PALI dan Muara Enim berada dalam klaster yang memiliki karakteristik persentase penduduk angkatan kerja dengan pendidikan terakhirnya belum pernah sekolah. Kedua kabupaten ini juga berada pada klaster dengan karakteristik persentase penduduk angkatan kerja yang bekerja memiliki status pekerjaan utamanya adalah pekerja tidak dibayar. Sehingga pada kedua kabupaten ini sangat perlu digalakan wajib belajar, pemberian 
beasiswa dan lain sebagainya, serta mendirikan balai-balai penyuluhan dan pelatihan untuk meningkatkan kerampilan penduduk angkatan kerja agar dapat berwirausaha, sehingga dapat mendorong terbukanya lapangan pekerjaan.

5. Kabupaten OKU Selatan walaupun tidak termasuk dalam klaster dengan TPT dan penggangguran yang tinggi, namun masuk dalam klaster dengan jumlah angkatan kerja yang bekerja dibidang industri pengolahan lebih sedikit dibanding kabupaten lainnya, OKU Selatan juga masuk dalam klaster dengan persentase angkatan kerja yang bekerja dengan status pekerjaan utamanya sebagai buruh/karyawan/pegawai yang kecil. Perlu dipertimbangkan untuk membuka industri-industri, meningkatkan kerja sama pemerintah dengan pihak swasta dalam membuka industri, khususnya di kabupaten OKU Selatan karena industri paling banyak dapat menyerap tenaga kerja. Sebaiknya tidak hanya terpusat di Kota Palembang, hal ini dapat menyebabkan kepadatan penduduk di ibu kota provinsi tersebut.

Penelitian ini menggunakan data sekunder yang bersumber dari BPS, sehingga untuk penelitian selanjutnya dapat diperluaskan dengan menggunakan data sampel angkatan kerja melalui wawancara dan survei langsung ke lapangan, dengan penambahan variabel lainnya, seperti latar belakang sosial dan psikologi para angkatan kerja.

\section{UCAPAN TERIMA KASIH}

Terimakasih kepada Universitas Sriwijaya yang telah memberikan dana kepada peneliti, sehingga artikel ini dapat dipublikasikan. Penelitian/publikasi artikel ini dibiayai oleh Anggaran DIPA Badan Layanan Umum Universitas Sriwijaya Tahun anggaran 2020. SP DIPA123.17.2.677515/2020. Revisi ke 01 tanggal 16 Maret 2020. Sesuai dengan SK Rektor Nomor: 0685/UN9/SK.BUK.KP/2020 Tanggal 15 Juli 2020.

\section{DAFTAR PUSTAKA}

Aitchison, J., \& Greenacre, M. (2002). Biplots of compositional data. Journal of the Royal Statistical Society. Series C: Applied Statistics, 51(4), 375-392. https://doi.org/10.1111/14679876.00275

Anik Nurul Aini, Diah Safitri, A. H. (2016). Analisis lapangan pekerjaan utama di jawa tengah berdasarkan grafik biplot sqrt ( square root biplot ). JURNAL GAUSSIAN, 5(1), 41-50.

BPS. (2019a). Industri Besar dan Sedang, Provinsi Sumatera Selatan 2019.

BPS. (2019b). Keadaan Angkatan Kerja di Indonesia 2019. 1(1), 1-8. http://dx.doi.org/10.1016/j.cirp.2016. 06.001\%0Ahttp://dx.doi.org/10.1016 /j.powtec.2016.12.055\%0Ahttps://doi .org/10.1016/j.ijfatigue.2019.02.006 \%0Ahttps://doi.org/10.1016/j.matlet. 2019.04.024\%0Ahttps://doi.org/10.1 016/j.matlet.2019.127252\%0Ahttp:// dx.doi.org/10.1016

BPS. (2019c). Keadaan Angkatan Kerja di Provinsi Sumatera Selatan 2019. PBS Sumatera Selatan.

BPS. (2020). Berita resmi statistik. Bps.Go.Id, 27, 1-52.

Gabriel, K. R. (1971). The biplot graphic display of Matrices with Application to Principal Component Analysis. Biometrika, 3(58), 153-164. http://www.econ.uba.ar/www/servici os/biblioteca/bibliotecadigital/institut os/cics/a3n2/cap8.pdf

Irwanto. (2019). Pengangguran di Sumsel Meningkat Hingga 185 Ribu Jiwa, Terbanyak Lulusan SMK | merdeka.com. Merdeka.Com. https://www.merdeka.com/peristiwa/ pengangguran-di-sumsel-meningkathingga-185-ribu-jiwa-terbanyaklulusan-smk.html

Jolliffe, I, T. (2002). Principal Component Analysis. In Springer. SpringerVerlag, New York. Inc.

Leleury, Z. A., \& Wokanubun, A. E. (2015). Analisis Biplot Pada Pemetaan Karakteristik Kemiskinan Di Provinsi Maluku. BAREKENG: Jurnal Ilmu 
Matematika Dan Terapan, 9(1), 2131.

https://doi.org/10.30598/barekengvol 9iss1pp21-31

Lloyd, C. D., Pawlowsky-glahn, V., Egozcue, J. J., Lloyd, C. D., Pawlowsky-glahn, V., \& Jos, J. (2012). Compositional Data Analysis in Population Studies. July 2013, 3741.

https://doi.org/10.1080/00045608.20 11.652855

Mattjik, A. A., \& Sumertajaya, I. M. (2011). Sidik Peubah Ganda (G. A. Wibawa (ed.); Pertama). IPB PRESS.

Pawlowsky-Glahn, V., Buccianti, A. (2011). Compositional Data Analysis: Theory and Applications. In Terra Nova (Vol. 1, Issue 1). John Wiley \& Sons, Ltd Registered. https://doi.org/10.1111/j.13653121.1989.tb00322.x

Templ M, Hron K, F. P. (2011). robCompositions: an R-package for robust statistical analysis of compositional data. In John Wiley and Sons. John Wiley and Sons. https://cran.rstudio.com/web/package s/robCompositions/robCompositions. pdf

Zubaidy, A., \& Handoyo, W. (2018). ANALISIS ANGKA TENAGA KERJA KOTA MALANG TAHUN 2018. Jurnal Pangripta, 1(2), 146162. 